\title{
Soil Solarization and Biological Control for Managing Mesocriconema xenoplax and Short Life in a Newly Established Peach Orchard
}

A. P. Nyczepir, Research Plant Pathologist (Nematologist), United States Department of Agriculture-Agricultural Research Service (USDA-ARS), Southeastern Fruit and Tree Nut Research Laboratory, Byron, GA 31008; D. A. Kluepfel, Research Plant Pathologist, USDA-ARS, Crops Pathology and Genetics Research Unit, University of California, Davis 95616; V. Waldrop, Chemist I, Clemson University, Department of Entomology, Soils, \& Plant Sciences, Clemson, SC 29634; and W. P. Wechter, Research Plant Pathologist, USDA-ARS, U. S. Vegetable Laboratory, Charleston, SC 29414

\begin{abstract}
Nyczepir, A. P., Kluepfel, D. A., Waldrop, V., and Wechter, W. P. 2012. Soil solarization and biological control for managing Mesocriconema xenoplax and short life in a newly established peach orchard. Plant Dis. 96:1309-1314.

The effects of soil solarization, with and without a Pseudomonas spp. cocktail or wheat rotation as alternatives to chemical control of Mesocriconema xenoplax, were investigated from 2004 to 2011. Preplant solarization and soil fumigation (67\% methyl bromide $+33 \%$ chloropicrin mixture; henceforth, referred to as $\mathrm{MBr}$ ) was initiated in 2004 in an orchard infested with M. xenoplax and a history of peach tree short life (PTSL). Plots consisted of nine treatments: (i) nonsolarized soil-alone, (ii) nonsolarized soil with bacteria cocktail (nonsolarbacteria), (iii) nonsolarized soil with wheat (nonsolar-wheat), (iv) nonsolarized soil with bacteria cocktail and wheat (nonsolar-bacteriawheat), (v) solarized soil-alone, (vi) solarized soil with bacteria cock-

tail (solar-bacteria), (vii) solarized soil with wheat (solar-wheat), (viii) solarized soil with bacteria cocktail and wheat (solar-bacteria-wheat), and (ix) preplant $\mathrm{MBr}$ fumigation. Peach trees were planted into all plots in 2005. Nematode populations were suppressed 20 months longer after orchard establishment in solar-alone and solar-wheat plots than solar-bacteria and solar-bacteria-wheat plots. Pseudomonas spp. cocktails did not have a pronounced effect in suppressing M. xenoplax in this study. Fumigation effect on M. xenoplax population density dissipated 24 months after application. Solar-wheat-treated soil was as effective as preplant $\mathrm{MBr}$ fumigation in increasing tree survival from PTSL for at least 6 years after orchard establishment.
\end{abstract}

In the southeastern United States, the productive life span of peach (Prunus persica (L.) Batsch) trees does not exceed 6 to 10 years on some sites due to premature tree death (1). Two causes of early tree mortality are a disease complex known as peach tree short life (PTSL) and Armillaria root rot $(12,19)$. PTSL is caused by a predisposition of trees to cold injury, bacterial canker (Pseudomonas syringae pv. syringae van Hall), or a combination of both, which results from parasitism by the ring nematode Mesocriconema xenoplax (Raski, 1952) Loof \& de Grisse, 1989 (= Criconemoides xenoplax (Raski, 1952) Loof and de Grisse, 1967) $(1,18,24)$. In closed-end field microplots, peach trees died of cold injury after 4 years of parasitism by $M$. xenoplax, whereas trees in noninfested soil survived (18). Moreover, development of PTSL on land that had not been planted with peach trees for $\geq 75$ years varied with exposure of trees to cumulative population levels of $M$. xenoplax (16). Such evidence indicates that PTSL complex is a nematode-associated disease and that the presence of $M$. xenoplax is required for the disease to occur. Additionally, M. xenoplax has been shown to make peach trees ('Suwanee') more susceptible to bacterial spot (Xanthomonas arboricola pv. pruni) (21). Trees growing in $M$. xenoplax-infested soil show evidence of more severe bacterial spot damage than trees exposed to low ring nematode populations.

Corresponding author: A. P. Nyczepir,

E-mail: Andy.Nyczepir@ars.usda.gov

Mention of trade names or commercial products in this publication are solely for the purpose of providing specific information and does not imply recommendation or endorsement by the United States Department of Agriculture.

Accepted for publication 29 March 2012.

http://dx.doi.org/10.1094/PDIS-05-11-0373-RE

This article is in the public domain and not copyrightable. It may be freely reprinted with customary crediting of the source. The American Phytopathological Society, 2012.
Preplant nematicides for ring nematode control are available in the Southeast (6). The current preplant nematicide recommendation for managing this nematode pathogen includes soil fumigation with Telone II (1,3-D) or Vapam (metam-sodium) (6). These are the only two preplant soil fumigants available to peach growers since the importation and manufacture of methyl bromide (MBr) was banned in the United States and Western Europe after January 2005 (4), due to its role in ozone depletion. As a result of reduced availability of pre- and postplant nematicides and the need for disease management practices that are less hazardous to humans, cheaper, and more environmentally safe, other nematode control options, such as biological control agents and soil solarization, are being investigated $(8,10)$.

Soil solarization is the hydrothermal heating of moist soils under clear polyethylene plastic during summer to achieve temperatures detrimental to soilborne pathogens and weeds $(8,22)$. Soil solarization, alone or in combination with other disease management practices, has been shown to be effective in reducing the inoculum density of many soilborne, disease-causing organisms, including plant-parasitic nematodes (22). Other beneficial effects of solarization include enhancement of competitive, thermotolerant populations of resident bacteria and fungi which limit subsequent colonization by less-competitive, antagonistic bacteria that were introduced into the system following solarization (5). Kluepfel et al. (10) substantiated this in an orchard study in which the native microbial community was significantly lowered both quantitatively and qualitatively by solarization. Furthermore, preplant soil solarization was effective in lowering the population density of $M$. xenoplax near economic threshold levels for up to 2 years on a PTSL site (10).

Pseudomonas sp. BG33R; a naturally derived, rifampin-resistant strain of BG33 isolated from a peach orchard site suppressive to PTSL, was demonstrated to suppress ring nematode reproduction in field soil under greenhouse conditions, as well as to inhibit egg hatch of the ring nematode in vitro (10). Seven additional fluorescent pseudomonad strains isolated from this same peach orchard inhibited ring nematode reproduction by more than $50 \%$ compared 
with the control treatment. All seven strains were identified as Pseudomonas spp. based on fatty acid analysis using MIDI Microbial Identification System (Microbial ID, Inc., Newark, DE) and subsequent $16 \mathrm{~S}$ rDNA sequence analysis $(10,25)$. Additional research is needed to investigate utilization of soil solarization alone and in combination with a cocktail of Pseudomonas strains delivered through irrigation system to manage ring nematode and PTSL.

The objective of this research was to evaluate efficiency of a cocktail of Pseudomonas spp. strains, alone or in combination with soil solarization or wheat, to suppress $M$. xenoplax populations and aid tree health during establishment of a young peach orchard.

\section{Materials and Methods}

Bacterial strains, media, and growth. Five Pseudomonas spp. strains previously demonstrated to suppress $M$. xenoplax multiplication were evaluated collectively (i.e., Pseudomonas spp. cocktail) under field conditions in this study $(9,10,26)$. The five Pseudomonas spp. culture strains included (i) Pseudomonas sp. BG33R (i.e., rifampin-resistant and known to kill $M$. xenoplax eggs), (ii) Pseudomonas sp. 134, (iii) Pseudomonas sp. 135, (iv) Pseudomonas sp. 136, and (v) Pseudomonas sp. 137. Each of these strains was grown separately in 14 liters of sterile Pseudomonas F Broth (tryptone at $10 \mathrm{~g} / \mathrm{liter}$, proteose peptone number 3 at $10 \mathrm{~g} / \mathrm{liter}$, dipotassium phosphate trihydrate at $1.5 \mathrm{~g} / \mathrm{liter}$, magnesium sulfate heptahydrate at $1.5 \mathrm{~g} / \mathrm{liter}$, and glycerol $10 \mathrm{~g} / \mathrm{liter}$ ). The broth for Pseudomonas sp. BG33R also included $140 \mathrm{ml}$ of filter-sterilized rifampin $(10 \mathrm{mg} / \mathrm{ml})$. Cultures were incubated for $24 \mathrm{~h}$ at $28^{\circ} \mathrm{C}$ in 19-liter carboys positioned horizontally on an orbital shaker, followed by addition of $140 \mathrm{ml}$ of a solution containing filter-sterilized 10\% sorbitol and 10\% inositol. Incubation then continued for another $24 \mathrm{~h}$ under the same conditions. Exposure to light was kept to a minimum during the $48 \mathrm{~h}$ of incubation. The cultures were transported to the field site, then combined and delivered through the irrigation system, as described below.

Field plot establishment. Various combinations of soil solarization, wheat rotation, and Pseudomonas spp. cocktail application treatments were compared with preplant $\mathrm{MBr}$ fumigation in a field experiment designed to investigate suppression of $M$. xenoplax populations and tree survival in a PTSL site over time. Plots were established in May 2004 at the United States Department of Agriculture-Agricultural Research Service Southeastern Fruit and Tree Nut Research Laboratory in Byron, Georgia. The study was conducted on a Faceville sandy loam soil $(78 \%$ sand, $14 \%$ silt, $8 \%$ clay [pH 5.7], and $1.79 \%$ organic matter) with a previous history of PTSL. Peach trees had been growing on this site since 1998 and were removed in May 2004. Immediately following tree removal in May, the test site was subsoiled (approximately $81 \mathrm{~cm}$-deep) and rotovated. The test site was divided into six adjacent blocks (planting rows) each measuring 87 by $6.1 \mathrm{~m}$, with treatment plots arranged in a randomized linear configuration down each of the six planting rows. Within each block, there were nine preplant soil treatment plots, which included (i) nonsolarized soil (nonsolaralone), (ii) nonsolarized soil with bacteria cocktail (nonsolar-bacteria), (iii) nonsolarized soil with wheat (nonsolar-wheat), (iv) nonsolarized soil with bacteria and wheat (nonsolar-bacteriawheat), (v) solarized soil-alone, (vi) solarized soil with bacteria cocktail (solar-bacteria), (vii) solarized soil with wheat (solarwheat), (viii) solarized soil with bacteria and wheat (solar-bacteriawheat), and (ix) $\mathrm{MBr}$ fumigation, which served as the positive control. Plots within a block were 8.5 by $3.1 \mathrm{~m}$. Treatments were arranged in a randomized complete block design with six blocks. Care was taken not to transport soil between the plots throughout all phases of the study.

The plots were re-rotovated on 22 June 2004, and a 4.0-mil (0.1 $\mathrm{mm}$ ), clear polyethylene tarp (approximately 8.5 by $3.0 \mathrm{~m}$ ) (NC420; Armin Plastics, City of Industry, CA) was stretched across the soil surface of all solarized plots and held in place by burying the edges. The plots were solarized from 23 June until 29 October. The nonsolarized plots in each replication were left fallow during the solarization period and weeds were controlled using glyphosate at label rates (Roundup; Monsanto, St. Louis). Soil temperatures were recorded Monday through Friday at approximately 3:00 p.m. using Tel-Tru thermometers (Cross System Components, Conyers, GA) that were placed in four solarized and four nonsolarized plots at depths of 10.2 and $30.5 \mathrm{~cm}$ during the period of solarization. At the end of the solarization period, tarps were slit with a knife (to release heat), and left in place until after $\mathrm{MBr}$ application to plots designated for fumigation.

Soil fumigant (67\% MBr, 33\% chloropicrin) was applied (455 $\mathrm{kg} / \mathrm{ha}$; Hendrix and Dail, Inc., Tifton, GA) in a strip (3.1 m wide) under tarp on 10 November 2004. Soil moisture (10- to $15-\mathrm{cm}$ depth) was adequate for fumigation such that, when the soil was compressed in the hand, it formed a ball that was easily broken with little disturbance (50 to $70 \%$ available soil moisture; 23 ). Tarps were removed from all plots on 19 November 2004.

Presolarization and prefumigation $M$. xenoplax populations in soil were determined on 22 June 2004 from four soil cores $(2.5 \mathrm{~cm}$ in diameter by $30 \mathrm{~cm}$ deep) collected within each plot throughout the test site. The four soil cores were composited by plot within each block for a total of 54 samples. The nematodes were extracted from a $100-\mathrm{cm}^{3}$ soil subsample with a semi-automatic elutriator (2) and centrifugal flotation (7), and counted.

All plots were planted to 'Dixiland' peach on Nemaguard rootstock at a tree spacing of 1.5 by $6.1 \mathrm{~m}$ in March 2005. Each plot had eight trees, the outer two of which served as borders with the six center trees as the experimental unit. All border trees were planted first. Using shovels, the remaining trees were planted by treatment in the following order: $\mathrm{MBr}$ fumigation, nonsolar-alone, nonsolar-wheat, solarized soil-alone, solar-wheat, solar-bacteria, solar-bacteria-wheat, nonsolar-bacteria, and nonsolar-bacteriawheat. All shovels were dipped in an approximately $1.05 \% \mathrm{NaOCl}$ solution (20\% Clorox) and rinsed with water between use in planting trees in each experimental unit. Trees planted in all bacteriatreated plots were first placed in an 18.9-liter bucket (i.e., six trees per bucket) containing approximately 10.8 liters of a combined bacterial suspension of the five Pseudomonas spp. strains (i.e., cocktail). The tree roots were submerged in the bacterial cocktail for approximately 30 minutes prior to planting. Total mean populations of the Pseudomonas spp. cocktail in each bucket were $6.55 \times$ $10^{8} \mathrm{CFU} / \mathrm{ml}$. Each planting hole also received approximately 1.8 liters of the cocktail solution, obtained from the bucket, before covering the tree roots with soil. All non-bacteria-treated trees were soaked in water alone prior to planting.

In addition to preplant applications, postplant applications of the Pseudomonas spp. cocktail were made in a $1.5-\mathrm{m}$ radius area on both sides of each treated tree on 6 July, 8 September, 13 October, 8 November, and 8 December 2005; 4 April, 4 May, 8 June, 14 September, 19 October, and 16 November 2006; 12 April, 5 June, 2 July, 6 September, 10 October, 20 November, and 20 December 2007; and 14 April, 20 May, 12 June, and 1 July 2008. Our hypothesis was that, by delivering the Pseudomonas spp. cocktail at regular intervals through the irrigation system to trees established in solarized and nonsolarized soils, populations of the introduced pseudomonads would be enhanced. This would result in improved soil and rhizosphere colonization and subsequent control of $M$. xenoplax populations. Postplant applications of the Pseudomonas spp. cocktail were made by applying the bacteria through a dedicated irrigation line fitted with a chemical injector. A second, water-only irrigation line that bypassed the injector applied only water to the noninoculated treatment trees. This allowed all treatment trees to receive equal volumes of water during the day of inoculation. Seven Supernet microjet-sprinklers (Netafim Irrigation, Inc., Fresno, CA) with a flow rate of 20.4 liters/h were installed in the tree row half-way between each test tree. Each microjet-sprinkler wetted a 3.0-m-diameter area. Total mean populations of the Pseudomonas spp. cocktail incorporated into the irrigation water were $4.04 \times 10^{9} \mathrm{CFU} / \mathrm{ml}$, with a mean dilution rate of $3.21 \times$ $10^{8} \mathrm{CFU} / \mathrm{ml}$ during a 4-h irrigation period. Water at approximately 142.9 liters/h was applied to each Pseudomonas spp. cocktail plot during the 4-h application period; the equivalent to wetting the top 
soil to a depth of $30.5 \mathrm{~cm}$, where the majority of plant-parasitic nematodes resided. Bacterial presence was confirmed in randomly selected, bacteria-treated plots during each application by collecting emitter water. The water samples were then serially diluted in sterile water and plated onto Pseudomonas Agar F (PAF; Difco Laboratories, Detroit).

All trees received annual applications of fertilizer (10-10-10 and 34-0-0 N-P-K), insecticides, fungicides, and herbicides, and were commercially pruned as recommended by the Georgia Cooperative Extension Service. Application rates of all applied materials were according to the schedule outlined in the guidelines for nonbearing and bearing trees $(6,11)$.

The preplant population density of $M$. xenoplax was determined on 2 March 2005 from six soil cores collected from within each plot throughout the test site, as described above for the presolarization and prefumigation sampling. Postplant population density of M. xenoplax was determined on 9 June, 6 September, and 2 December 2005; 29 March, 7 June, 12 September, and 15 November 2006; 9 March, 5 June, 4 September, and 12 December 2007; 27 March, 10 June, 17 September, and 9 December 2008; 12 March, 8 June, and 2 September 2009; and 13 January, 23 March, 9 June, 2 September, and 3 December 2010 from one soil core collected within the drip line of each of six test trees of each experimental unit. The six soil cores were composited and nematodes were extracted from a $100-\mathrm{cm}^{3}$ subsample as described above.

The area within the plots designated for wheat was shallow disked $(10.0 \mathrm{~cm})$ before AGS-2010 wheat was planted at a seeding rate of $136 \mathrm{~kg} / \mathrm{ha}$ with an EV-N-SPRED broadcast spreader (Earthway Products, Inc., Bristol, IN) on 23 November 2005, 7 December 2006, 19 November 2007, 22 October 2008, 17 November 2009, and 15 December 2010. Wheat plots did not receive supplemental fertilizer other than that used in fertilizing the trees. The purpose of interplanting the wheat around the peach trees was not to suppress the M. xenoplax populations (14) but, rather, to have the wheat (roots) serve as an overwintering host for the bacteria (D. Kluepfel, unpublished) while peach trees were dormant. The wheat was allowed to reach maturity; then, the stalks were mowed with a weed-eater and the stubble was allowed to remain on the soil surface throughout the summer months, until the soil was disked in the fall each year.

Trunk diameters were measured at $20.3 \mathrm{~cm}$ above the soil surface on 24 February 2006, 28 February 2007, 12 February 2008, 29 January 2009, 1 February 2010, and 21 January 2011. Tree mortality as a result of bacterial canker infection or cold injury was recorded on 24 May 2006, 2 May 2007, 22 May 2008, 14 May 2009, 3 June 2010, and 2 May 2011 to monitor PTSL in the site.

Statistics. Nematode data were subjected to analysis of variance (ANOVA) with the general linear models procedure of SAS (SAS Institute, Cary, NC). For the presolarization and prefumigation sampling dates, nematode population densities were compared among the nine designated treatments-(i) nonsolarized soil, (ii) nonsolarized soil with bacteria, (iii) nonsolarized soil with wheat, (iv) nonsolarized soil with bacteria and wheat, (v) solarized soil alone, (vi) solarized soil with bacteria, (vii) solarized soil with wheat, (viii) solarized soil with bacteria and wheat, and (ix) $\mathrm{MBr}$ fumigation-before the soil was solarized or fumigated. For the preplant sampling date (before the Pseudomonas spp. cocktail and wheat treatments were applied), nematode densities were compared among solarized, nonsolarized, and $\mathrm{MBr}$-treated plots. For the postplant sampling dates, nematode densities were compared among all nine treatments, except on the first postplant sampling date (June 2005), when only nonsolarized soil alone, solarized soil alone, and $\mathrm{MBr}$ plots were compared (because the Pseudomonas spp. cocktail and wheat plots were not yet established at the time of sampling). Nematode density means for the presolarization and prefumigation sampling and postplant sampling dates were compared according to the Fisher protected least significant difference (LSD) test, following a significant $F$ test. For the preplant sampling dates, nematode density means for the combined solarized and nonsolarized treatments were compared with the $\mathrm{MBr}$ treatment using Dunnett's test, following a significant $F$ test. Treatment effects on tree trunk diameter means also were determined by ANOVA, followed by the Fisher protected LSD test, following a significant $F$ test. Finally, the proportion of peach tree survival within each experimental unit for the solarized, nonsolarized, and $\mathrm{MBr}$ soil fumigation treatments were tested for mean separation for each sampling date by ANOVA. Only significant differences $(P$ $\leq 0.05$ ) will be discussed unless stated otherwise.

\section{Results and Discussion}

Soil temperatures. Maximum soil temperatures reached $48.3^{\circ} \mathrm{C}$ at $10.2 \mathrm{~cm}$ and $38.3^{\circ} \mathrm{C}$ at $30.5 \mathrm{~cm}$ depth in the solarized plots in July, compared with $43.3^{\circ} \mathrm{C}$ at $10.2 \mathrm{~cm}$ (July) and $37.8^{\circ} \mathrm{C}$ at 30.5 $\mathrm{cm}$ (August) depth in the nonsolarized plots (Table 1). Furthermore, the 5-month average daily soil temperature in the solarized plots was approximately $4^{\circ} \mathrm{C}$ greater at both the $10.2-$ and $30.5-\mathrm{cm}$ depths compared with the nonsolarized plots.

Using heat to manage nematode populations is one of the oldest physical methods known (3). Nematodes are known to be sensitive to heat, with most life-stage mortality thresholds occurring between 44.4 and $48.0^{\circ} \mathrm{C}$. In contrast, populations of pathogenic fungi have been reported to be greatly reduced at temperatures between 40 and $50^{\circ} \mathrm{C}(8)$. In our study, soil temperatures $>44^{\circ} \mathrm{C}$ only occurred in solarized plots at $10.2 \mathrm{~cm}$ in July (10 days) and August (5 days) during the 18.3-week solarization period (data not shown). Only during one day in July at $10.2 \mathrm{~cm}$ was the soil temperature $>48^{\circ} \mathrm{C}$. Soil temperatures $>44^{\circ} \mathrm{C}$ did not occur at the $30.5-\mathrm{cm}$ depth in the solarized or nonsolarized plots. In the present study, the soil temperatures in solarized plots at $10.2 \mathrm{~cm}$ were

Table 1. Soil temperatures at 10.2- and 30.5-cm depths in solarized and nonsolarized plots, June through August 2004, Byron, GA

\begin{tabular}{|c|c|c|c|c|c|}
\hline \multirow[b]{3}{*}{ Month } & \multirow[b]{3}{*}{ Depth $(\mathbf{c m})^{\mathrm{z}}$} & \multicolumn{4}{|c|}{ Soil temperature $\left({ }^{\circ} \mathbf{C}\right)^{y}$} \\
\hline & & \multicolumn{2}{|c|}{ Mean } & \multicolumn{2}{|c|}{ Maximum } \\
\hline & & Solarized & Nonsolarized & Solarized & Nonsolarized \\
\hline \multirow[t]{2}{*}{ June } & 10.2 & 36.5 & 32.3 & 42.2 & 35.0 \\
\hline & 30.5 & 31.8 & 28.2 & 33.3 & 28.9 \\
\hline \multirow[t]{2}{*}{ July } & 10.2 & 41.0 & 38.1 & 48.3 & 43.3 \\
\hline & 30.5 & 35.3 & 32.0 & 38.3 & 37.2 \\
\hline \multirow[t]{2}{*}{ August } & 10.2 & 38.2 & 34.2 & 46.1 & 42.8 \\
\hline & 30.5 & 34.1 & 30.2 & 37.8 & 37.8 \\
\hline \multirow[t]{2}{*}{ September } & 10.2 & 34.0 & 29.7 & 41.1 & 37.8 \\
\hline & 30.5 & 30.0 & 26.3 & 34.4 & 32.2 \\
\hline \multirow[t]{2}{*}{ October } & 10.2 & 30.7 & 26.2 & 38.3 & 31.1 \\
\hline & 30.5 & 27.3 & 22.9 & 31.7 & 25.6 \\
\hline
\end{tabular}

${ }^{\mathrm{x}}$ Temperatures were recorded daily at approximately 3:00 p.m. using a soil thermometer. Temperature data were collected from 24 June to 29 October 2004 (excluding weekends).

${ }^{y}$ Mean daily temperature and highest temperature recorded for the respective month.

${ }^{\mathrm{z}}$ Thermometers were buried at each depth (i.e., 10.2 or $30.5 \mathrm{~cm}$ ) in four randomly selected solarized and four nonsolarized plots in the test site. 
within the efficacious range for killing plant-parasitic nematodes and some pathogenic fungi. It is possible that, by delivering efficacious temperatures to depths greater than $10.2 \mathrm{~cm}$, further suppression of ring nematode populations could result in additional reductions in PTSL incidence.

M. xenoplax evaluation. The mean population density of $M$. xenoplax prior to soil solarization and $\mathrm{MBr}$ treatment for six replications was $60 \pm 8.3$ (standard error)/ $100 \mathrm{~cm}^{3}$ of soil in June 2004. In March 2005, the nematode population density following establishment of the solarized and $\mathrm{MBr}$ fumigation plots but prior to replanting peach trees was greatest $(P \leq 0.05)$ in the nonsolarized plots $\left(21 \mathrm{M}\right.$. xenoplax $/ 100 \mathrm{~cm}^{3}$ of soil), intermediate in the solarized plots (6 M. xenoplax $/ 100 \mathrm{~cm}^{3}$ of soil), and lowest in $\mathrm{MBr}$-fumigated plots $\left(0 \mathrm{M}\right.$. xenoplax $/ 100 \mathrm{~cm}^{3}$ of soil). Furthermore, the $4^{\circ} \mathrm{C}$ differential in soil temperature between solarized $\left(36.1^{\circ} \mathrm{C}\right.$ at $10.2 \mathrm{~cm}$ and $31.7^{\circ} \mathrm{C}$ at $\left.30.5 \mathrm{~cm}\right)$ and nonsolarized $\left(32.1^{\circ} \mathrm{C}\right.$ at $10.2 \mathrm{~cm}$ and $27.9^{\circ} \mathrm{C}$ at $\left.30.5 \mathrm{~cm}\right)$ plots mentioned previously may also explain the approximate temperature threshold needed to significantly lower ring nematode populations prior to orchard establishment.

Three months after orchard establishment (June 2005), nematode populations were greater in nonsolar-alone plots than in the solarized soil-alone and MBr-fumigated plots (Table 2). No differences in ring nematode population were detected between the solarized soil-alone and $\mathrm{MBr}$ fumigation. Furthermore, 12 months after orchard establishment (March 2006), all nonsolar plots had greater $(P \leq 0.05)$ nematode populations than all solarized and $\mathrm{MBr}$-fumigated plots. No differences in ring nematode population were detected among any of the solarized plots and $\mathrm{MBr}$ fumigation. Presence of the Pseudomonas spp. cocktail or wheat did not suppress $(P \leq 0.05) M$. xenoplax population density as well as soil solarization. Therefore, postplant bacterial cocktail applications were discontinued after July 2008. The lack of nematode suppression in the presence of the Pseudomonas spp. cocktail did not substantiate our observations in previous field studies with solarization combined with Pseudomonas sp. BG33R $(10,15)$. In our first solarization test, $M$. xenoplax populations were significantly lower $(P \leq 0.05)$ in solarized plots that were initially inoculated with Pseudomonas sp. BG33R at planting and again 8 months later compared with plots that were only solarized. However, this enhanced reduction in $M$. xenoplax populations in plots where Pseudomonas sp. BG33R was introduced decreased over time. One possible explanation as to why no suppression in M. xenoplax population was observed in the presence of the Pseudomonas spp. cocktail in the current study is that competition or antagonism occurred among the five Pseudomonas spp. strains in the soil, thus limiting their individual, deleterious effects on nematode reproduction. In contrast, the suppressive effect of solarization on ring nematode populations was sustained for more than 1 year. In the present study, populations of M. xenoplax were lower in solarized plots for up to 17 months longer (March 2006) than in nonsolarized plots. During this same time, M. xenoplax populations were statistically similar among solarized and $\mathrm{MBr}$-treated plots. Twenty-four months after $\mathrm{MBr}$ application (November 2006), the nematode population density in the fumigated plots did not differ from those in the nonsolar-alone, nonsolar-wheat, and four solarized treatment plots, even though no ring nematodes were detected immediately after fumigation. The lack of statistical significance may be attributable to high variability in M. xenoplax population densities between the nonsolar treatments and $\mathrm{MBr}$ fumigation plots on this sampling date. It was not until 28 months after $\mathrm{MBr}$ application (March 2007) that M. xenoplax was first detected in the MBr-fumigated plots. The advantage of using preplant fumigation, one component of the 10-Point Management Program (1) to control M. xenoplax in the PTSL disease complex, was confirmed in this study, given that $\mathrm{MBr}$ is a broad-spectrum pesticide that controls not only nematodes but also other microorganisms and certain weeds. However, it is not unusual for the effect of preplant fumigation to diminish over time. In South Carolina, Zehr and Golden (27) reported that managing $M$. xenoplax with a preplant application of 1,3-D was not effective for more than 2 years following initial treatment. Our results substantiated those of Nyczepir and Bertrand (13) and Sharpe et al. (20), who both reported that a resurgence in the mean $M$. xenoplax population density on 'Nemaguard' rootstock occurred approximately 25 months after a preplant treatment with $\mathrm{MBr}$. At subsequent sampling dates from September 2007 to December 2008, the ring nematode population density in $\mathrm{MBr}$-fumigated and the four solarized plots generally increased, compared with the four nonsolarized plots (Table 2), such that the $M$. xenoplax population density was greater $(P \leq$ 0.05) on three of the five sampling dates in $\mathrm{MBr}$-treated plots than in all four nonsolarized plots. One explanation for this occurrence may be that trees growing in solarized and $\mathrm{MBr}$-fumigated soil were healthier early on, resulting in increased feeder root abun-

Table 2. Populations of Mesocriconema xenoplax in a peach orchard, as influenced by soil solarization, Pseudomonas spp. bacteria cocktail, wheat intercropping, or preplant fumigation with methyl bromide-chloropicrin, 2005 to 2008, Byron, GA ${ }^{u}$

\begin{tabular}{|c|c|c|c|c|c|c|c|c|c|c|}
\hline \multirow[b]{3}{*}{ Treatments $^{\mathrm{v}}$} & \multicolumn{10}{|c|}{ M. xenoplax per $100 \mathrm{~cm}^{3}$ of soil } \\
\hline & \multicolumn{2}{|r|}{2005} & \multicolumn{2}{|c|}{2006} & \multicolumn{3}{|c|}{2007} & \multicolumn{3}{|c|}{2008} \\
\hline & $\begin{array}{c}9 \\
\text { June }\end{array}$ & $\begin{array}{c}2 \\
\text { December }\end{array}$ & $\begin{array}{c}29 \\
\text { March }^{w}\end{array}$ & $\begin{array}{c}15 \\
\text { November }^{\mathrm{x}}\end{array}$ & $\begin{array}{c}9 \\
\operatorname{March}^{x}\end{array}$ & $\begin{array}{c}4 \\
\text { September }\end{array}$ & $\begin{array}{c}12 \\
\text { December }^{y}\end{array}$ & $\begin{array}{c}27 \\
\text { March }^{w}\end{array}$ & $\begin{array}{c}17 \\
\text { September }\end{array}$ & $\begin{array}{c}9 \\
\text { December }^{w}\end{array}$ \\
\hline Nonsolar-alone & $75 \mathrm{a}$ & $70 \mathrm{a}$ & $113 \mathrm{a}$ & $123 \mathrm{ab}$ & $186 \mathrm{ab}$ & $207 \mathrm{bc}$ & $978 \mathrm{abc}$ & 501 cde & $75 \mathrm{c}$ & $36 \mathrm{~d}$ \\
\hline Nonsolar-bacteria-wheat & $63^{\mathrm{z}}$ & $58 \mathrm{a}$ & $143 \mathrm{a}$ & $260 \mathrm{a}$ & $290 \mathrm{a}$ & $153 \mathrm{c}$ & $420 \mathrm{bc}$ & $186 \mathrm{e}$ & $57 \mathrm{c}$ & $78 \mathrm{~cd}$ \\
\hline Nonsolar-wheat & $58^{\mathrm{z}}$ & $33 \mathrm{a}$ & $128 \mathrm{a}$ & $88 \mathrm{ab}$ & $215 \mathrm{ab}$ & $210 \mathrm{bc}$ & $831 \mathrm{abc}$ & $306 \mathrm{de}$ & $87 \mathrm{c}$ & $135 \mathrm{bcd}$ \\
\hline Nonsolar-bacteria & $13^{\mathrm{z}}$ & $30 \mathrm{a}$ & $168 \mathrm{a}$ & $235 \mathrm{a}$ & $339 \mathrm{a}$ & $168 \mathrm{c}$ & $309 \mathrm{c}$ & $117 \mathrm{e}$ & $51 \mathrm{c}$ & $135 \mathrm{bcd}$ \\
\hline Solar-wheat & $10^{\mathrm{z}}$ & $0 \mathrm{a}$ & $13 \mathrm{~b}$ & $40 \mathrm{~b}$ & $253 \mathrm{a}$ & $920 \mathrm{a}$ & $832 \mathrm{abc}$ & $1,349 \mathrm{abc}$ & $704 \mathrm{ab}$ & $168 \mathrm{bcd}$ \\
\hline Solar-bacteria & $8^{\mathrm{z}}$ & $5 \mathrm{a}$ & $3 \mathrm{~b}$ & $128 \mathrm{ab}$ & $303 \mathrm{a}$ & $906 \mathrm{ab}$ & $1,622 \mathrm{a}$ & 977 bcde & $340 \mathrm{bc}$ & $335 \mathrm{bc}$ \\
\hline Solar-bacteria-wheat & $5^{\mathrm{z}}$ & $0 \mathrm{a}$ & $3 \mathrm{~b}$ & $130 \mathrm{ab}$ & $243 \mathrm{a}$ & $1,162 \mathrm{a}$ & $1,564 \mathrm{ab}$ & $1,288 \mathrm{abcd}$ & $423 \mathrm{bc}$ & $368 \mathrm{~b}$ \\
\hline Solar-alone & $0 \mathrm{~b}$ & $0 \mathrm{a}$ & $10 \mathrm{~b}$ & $10 \mathrm{~b}$ & $143 \mathrm{ab}$ & $828 \mathrm{abc}$ & $1,810 \mathrm{a}$ & $1,932 \mathrm{ab}$ & $630 \mathrm{ab}$ & $215 \mathrm{bcd}$ \\
\hline $\mathrm{MBr}$ & $0 \mathrm{~b}$ & $0 \mathrm{a}$ & $0 \mathrm{~b}$ & $0 \mathrm{~b}$ & $18 \mathrm{~b}$ & $618 \mathrm{abc}$ & $1,533 \mathrm{ab}$ & $1,933 \mathrm{a}$ & $1,073 \mathrm{a}$ & $688 \mathrm{a}$ \\
\hline
\end{tabular}

"Data are means of six replications per treatment, except that 15 November 2006 to 9 December 2008 had five replicates for nonsolar-alone, and 4 September 2007 to 9 December 2008 had five replicates for nonsolar-bacteria-wheat, nonsolar-bacteria, and nonsolar-wheat.

${ }^{\vee}$ Soil was solarized from 23 June until 29 October 2004. Wheat = wheat was planted at a seeding rate of $136 \mathrm{~kg} / \mathrm{ha}$ on $23 \mathrm{November} 2005,7 \mathrm{December}$ 2006, 19 November 2007, 22 October 2008, 17 November 2009, and 15 December 2010. Bacteria = Pseudomonas spp. cocktails were applied at a mean dilution rate of $3.21 \times 10^{8} \mathrm{CFU} / \mathrm{ml}$ during a 4-h irrigation period on 6 July, 8 September, 13 October, 8 November, and 8 December 2005; 4 April, 4 May, 8 June, 14 September, 19 October, and 16 November 2006; 12 April, 5 June, 2 July, 6 September, 10 October, 20 November, and 20 December 2007; and 14 April, 20 May, 12 June, and 1 July 2008. MBr = soil fumigant (67\% methyl bromide:33\% chloropicrin) was applied at a rate of $455 \mathrm{~kg} / \mathrm{ha}$; application date was 10 November 2004. Tarps were removed from all plots on 19 November 2004

${ }^{\text {w }}$ Nematode means within a column followed by the same letter are not different $(P \leq 0.05)$ according to Fisher's least significant difference.

${ }^{x}$ Nematode means within a column followed by the same letter are not different $(P<0.10)$ according to Fisher's least significant difference.

y Nematode means within a column followed by the same letter are not different $(P=0.12)$ according to Fisher's least significant difference.

z Treatment not included in analysis since the Pseudomonas spp. cocktail and wheat plots were not yet established at the time of sampling. 
dance (i.e., food source), which supported increased nematode reproduction during this period of time. In contrast, trees growing in nonsolarized soil were weaker, resulting in a reduced food source, which is known to limit nematode reproduction (17). From June 2009 (55 months after $\mathrm{MBr}$ application) to December 2010 (73 months after $\mathrm{MBr}$ application), M. xenoplax population densities did not differ among any of the soil treatments, thus indicating stabilization in ring nematode population density as related to soil treatment effect. For example, in December 2010, mean ring nematode populations in the four nonsolarized, four solarized, and $\mathrm{MBr}-$ fumigated treatment plots were $123 \mathrm{M}$. xenoplax $/ 100 \mathrm{~cm}^{3}$ of soil (range 84 to 156), 105 M. xenoplax $/ 100 \mathrm{~cm}^{3}$ of soil (range 75 to 158), and 130 M. xenoplax $/ 100 \mathrm{~cm}^{3}$ of soil, respectively. A second explanation as to why $M$. xenoplax became established in the solar and $\mathrm{MBr}$ plots over time may be the result of subsoiling that occurred during site preparation of the plots, as previously reported (16). Subsequently, over time, the roots among adjacent plots eventually grew down the subsoil furrows, which aided nematode movement and establishment of $M$. xenoplax into solar and $\mathrm{MBr}$ plots from other plots that already had established ring nematode populations. A third explanation may be the suppression of nematode antagonists by the nematicide and soil solarization process that also might have favored the increase of M. xenoplax in the MBr-fumigated and solarized plots.

Differences in trunk diameter were detected among some of the solarized, nonsolarized, and $\mathrm{MBr}$ fumigation treatments on five of six sampling dates (Table 3). In February 2006 (11 months after orchard establishment), trunk diameter was smallest $(P \leq 0.01)$ in nonsolar-wheat plots, intermediate in solar-bacteria and solarbacteria-wheat, and greatest in fumigated plots. Twenty-three months after orchard establishment (February 2007), tree growth again was greatest $(P=0.10)$ in the $\mathrm{MBr}$-fumigated plots and lowest in nonsolar-wheat plots. The effect of solarization, Pseudomonas spp. cocktail, or wheat interplanting on tree growth at and after 23 months after orchard establishment (February 2007) was not apparent among the treatments. Tree growth at 46 months after orchard establishment (January 2009) and thereafter was generally greater in the nonsolarized plots than the solarized and MBr-fumigated plots. One possible explanation for this reversal in treatment effect on increased tree growth might be related to number of test trees surviving within the respective treatment plots. More test trees surviving in a particular treatment over time (i.e., MBr-fumigated and solarized plots; Table 3) would result in increased canopy and, therefore, increased competition for space and light among the trees, thus resulting in a slower-growing trees. In con- trast, fewer living test trees resulting from increased PTSL tree mortality within a particular treatment (i.e., up to $71 \%$ tree mortality in nonsolarized plots) would mean less competition for tree space, therefore resulting in larger trees. These remaining larger trees would, therefore, receive more pruning wounds per tree, which would also induce additional stress that may contribute to an increase in PTSL tree mortality. To circumvent pruning effect on PTSL incidences in this study, trees were always pruned after 15 February (2006 to 2011) $(1,6)$.

Some of the experimental peach trees developed typical PTSL symptoms and died during the experiment. In May 2006 (14 months after orchard establishment), more $(P \leq 0.05)$ trees in the nonsolarized soil-alone, nonsolar-bacteria, and nonsolar-wheat plots developed PTSL symptoms and died than in all four solarized and MBr-fumigated plots (Table 3). In May 2007 (26 months after orchard establishment), PTSL tree mortality in all nonsolarized soil plots was greater $(P \leq 0.05)$ than in all solarized and $\mathrm{MBr}$-fumigated plots. No differences in PTSL tree death were detected among all the solarized plots and the $\mathrm{MBr}$-fumigated soil plots. Thirty-eight months after orchard establishment (May 2008), tree survival in solar soil-alone, solar-wheat, and solar-bacteria-wheat was comparable with trees growing in $\mathrm{MBr}$-fumigated soil. In May 2009 (50 months after orchard establishment) and June 2010 (63 months after orchard establishment), tree survival was highest in $\mathrm{MBr}$-fumigated soil (89\%) and lowest in nonsolar-bacteria-wheat plots $(29 \%)$. Although tree survival in solar-wheat plots $(80 \%)$ was greater $(P \leq 0.05)$ than tree survival in the four nonsolarized treatment plots, tree survival in solar-wheat plots did not differ from MBr-fumigated plots. In May 2011 (74 months after orchard establishment), four trees succumbed to PTSL death (i.e., three trees in solar-wheat plots and one tree in $\mathrm{MBr}$-fumigated plots). However, tree survival in solar-wheat $(71 \%)$ and $\mathrm{MBr}$-fumigated soil $(86 \%)$ generally remained statistically similar between and among treatments when compared with the previous two rating periods (Table 3 ). These results clearly demonstrate the benefit of suppression in ring nematode population density in extending peach tree longevity on a PTSL site. In addition, our results indicate that use of alternatives to $\mathrm{MBr}$ soil fumigation did not negatively impact long-term tree survival.

In general, peach growers in the southeastern United States would consider $\geq 50 \%$ tree loss in a particular block unacceptable, and would remove the remaining live trees and replant or utilize the land for another crop. In our study, tree mortality of $\geq 50 \%$ occurred in all four nonsolar treatment plots at 26 months after orchard establishment (May 2007). Greater early tree mortality in

Table 3. Effect of soil solarization, Pseudomonas spp. bacteria cocktail, wheat interplanting, or preplant fumigation with methyl bromide-chloropicrin on trunk diameter of peach trees (Prunus persica 'Dixiland'/'Nemaguard') and tree mortality due to peach tree short life (PTSL), 2006 to 2011, Byron, GA ${ }^{\mathrm{w}}$

\begin{tabular}{|c|c|c|c|c|c|c|c|c|c|c|c|c|}
\hline \multirow[b]{2}{*}{ Treatment $^{\mathrm{x}}$} & \multicolumn{6}{|c|}{ Trunk diameter $(\mathbf{m m})$} & \multicolumn{6}{|c|}{ Cumulative PTSL mortality (\%) } \\
\hline & $\begin{array}{c}24 \text { Feb } \\
2006^{y}\end{array}$ & $\begin{array}{c}28 \text { Feb } \\
2007^{z}\end{array}$ & $\begin{array}{l}12 \text { Feb } \\
2008^{y}\end{array}$ & $\begin{array}{c}29 \mathrm{Jan}^{2009^{y}}\end{array}$ & $\begin{array}{l}1 \text { Feb } \\
2010^{y}\end{array}$ & $\begin{array}{l}24 \text { Jan } \\
2011^{y}\end{array}$ & $\begin{array}{c}24 \text { May } \\
2006^{y}\end{array}$ & $\begin{array}{l}2 \text { May } \\
2007^{y}\end{array}$ & $\begin{array}{c}22 \text { May } \\
2008^{y}\end{array}$ & $\begin{array}{c}14 \text { May } \\
2009^{y}\end{array}$ & $\begin{array}{l}3 \text { June } \\
2010^{y}\end{array}$ & $\begin{array}{l}2 \text { May } \\
2011^{y}\end{array}$ \\
\hline Nonsolar-alone & $26.3 \mathrm{bc}$ & $49.2 \mathrm{bc}$ & $69.4 \mathrm{a}$ & $85.9 \mathrm{~b}$ & $104.0 \mathrm{abc}$ & $114.9 \mathrm{bc}$ & $36 \mathrm{~b}$ & $53 \mathrm{~b}$ & $56 \mathrm{c}$ & $63 \mathrm{def}$ & $63 \mathrm{def}$ & $63 \mathrm{de}$ \\
\hline Nonsolar-bac-wheat & $27.9 \mathrm{bc}$ & $50.3 \mathrm{abc}$ & $75.5 \mathrm{a}$ & $96.5 \mathrm{a}$ & $110.5 \mathrm{a}$ & $128.8 \mathrm{a}$ & $19 \mathrm{ab}$ & $56 \mathrm{~b}$ & $63 \mathrm{c}$ & $71 \mathrm{f}$ & $71 \mathrm{f}$ & $71 \mathrm{e}$ \\
\hline Nonsolar-wheat & $25.4 \mathrm{c}$ & $48.1 \mathrm{c}$ & $73.9 \mathrm{a}$ & $88.6 \mathrm{~b}$ & $109.5 \mathrm{a}$ & $119.3 \mathrm{ab}$ & $36 \mathrm{~b}$ & $56 \mathrm{~b}$ & $61 \mathrm{c}$ & 66 ef & 68 ef & $68 \mathrm{e}$ \\
\hline Nonsolar-bac & $27.5 \mathrm{bc}$ & $52.3 \mathrm{ab}$ & $74.3 \mathrm{a}$ & $89.7 \mathrm{ab}$ & $106.6 \mathrm{ab}$ & $117.8 \mathrm{abc}$ & $39 \mathrm{~b}$ & $50 \mathrm{~b}$ & $52 \mathrm{bc}$ & $58 \mathrm{cdef}$ & $58 \mathrm{cdef}$ & $58 \mathrm{cde}$ \\
\hline Solar-wheat & $27.9 \mathrm{bc}$ & $48.9 \mathrm{bc}$ & $70.6 \mathrm{a}$ & $83.3 \mathrm{~b}$ & $92.2 \mathrm{c}$ & $105.7 \mathrm{c}$ & $0 \mathrm{a}$ & $8 \mathrm{a}$ & $11 \mathrm{a}$ & $20 \mathrm{ab}$ & $20 \mathrm{ab}$ & $29 \mathrm{ab}$ \\
\hline Solar-bac & $28.9 \mathrm{~b}$ & $51.9 \mathrm{abc}$ & $74.1 \mathrm{a}$ & $88.8 \mathrm{~b}$ & $99.7 \mathrm{abc}$ & $115.1 \mathrm{bc}$ & $0 \mathrm{a}$ & $16 \mathrm{a}$ & $27 \mathrm{ab}$ & 38 abcd & $38 \mathrm{abcd}$ & 38 abcd \\
\hline Solar-bac-wheat & $29.6 \mathrm{~b}$ & $51.5 \mathrm{abc}$ & $71.0 \mathrm{a}$ & $85.5 \mathrm{~b}$ & $99.6 \mathrm{abc}$ & $111.9 \mathrm{bc}$ & $0 \mathrm{a}$ & $11 \mathrm{a}$ & $12 \mathrm{a}$ & $34 \mathrm{abc}$ & $34 \mathrm{abc}$ & $34 \mathrm{abc}$ \\
\hline Solar-alone & $27.7 \mathrm{bc}$ & $49.5 \mathrm{bc}$ & $68.7 \mathrm{a}$ & $82.8 \mathrm{~b}$ & $95.0 \mathrm{bc}$ & $106.7 \mathrm{bc}$ & $0 \mathrm{a}$ & $14 \mathrm{a}$ & $21 \mathrm{a}$ & 41 bcde & 41 bcde & 41 bcde \\
\hline $\mathrm{MBr}$ & $33.5 \mathrm{a}$ & $53.8 \mathrm{a}$ & $71.7 \mathrm{a}$ & $84.0 \mathrm{~b}$ & $93.1 \mathrm{c}$ & $105.8 \mathrm{bc}$ & $0 \mathrm{a}$ & $0 \mathrm{a}$ & $3 \mathrm{a}$ & $11 \mathrm{a}$ & $11 \mathrm{a}$ & $14 \mathrm{a}$ \\
\hline
\end{tabular}

w Data are means of six replications per treatment, except for trunk diameter on 12 February 2008 to 24 January 2011, which had five replicates for nonsolaralone, nonsolar-bacteria-wheat, and nonsolar-bacteria; and nonsolar-wheat and for solar-alone on 24 January 2011, which had five replicates.

${ }^{x}$ Soil was solarized from 23 June to 29 October 2004. Wheat $=$ wheat was planted at a seeding rate of $136 \mathrm{~kg} / \mathrm{ha}$ on 23 November 2005,7 December 2006 , 19 November 2007, 22 October 2008, 17 November 2009, and 15 December 2010. Bac = Pseudomonas spp. bacteria cocktails were applied at a mean dilution rate of $3.21 \times 10^{8} \mathrm{CFU} / \mathrm{ml}$ during a 4-h irrigation period on 6 July, 8 September, 13 October, 8 November, and 8 December 2005; 4 April, 4 May, 8 June, 14 September, 19 October, and 16 November 2006; 12 April, 5 June, 2 July, 6 September, 10 October, 20 November, and 20 December 2007 ; and 14 April, 20 May, 12 June, and $1 \mathrm{July} 2008 . \mathrm{MBr}=$ soil fumigant (67\% methyl bromide:33\% chloropicrin) was applied at a rate of $455 \mathrm{~kg} / \mathrm{ha}$ on $10 \mathrm{November}$ 2004. Tarps were removed from all plots on 19 November 2004

${ }^{y}$ Means within a column followed by the same letter are not different $(P \leq 0.05)$ according to Fisher's least significant difference.

${ }^{\mathrm{z}}$ Means within a column followed by the same letter are not different $(P=0.10)$ according to Fisher's least significant difference. 
the nonsolarized plots (50 to 56\%) compared with the solarized (8 to $16 \%)$ and $\mathrm{MBr}$-fumigated plots $(0 \%)$ just 2 years postplanting could be attributed to a relatively high $M$. xenoplax population at the time of orchard establishment in March 2005 (Table 2). The experimental orchard site has a known history of PTSL, and has been replanted to peach four times over the past 40 years. It has been reported that PTSL development is dependent upon cumulative exposure of trees to increasing populations of M. xenoplax (16). In the present study, the ring nematode population density in most nonsolarized plots from 3 (June 2005) to 12 (March 2006) months after orchard establishment was higher than in solarized and $\mathrm{MBr}$-fumigated plots (Table 2). Therefore, trees in nonsolarized plots were exposed to greater nematode-feeding-induced stress during a sensitive phenological time period, which resulted in elevated PTSL tree death.

Tree survival in the solar-wheat plots was not different $(P \leq$ 0.05) from that in the MBr-fumigated plots 6 years after orchard establishment. We are uncertain of the mechanism or mechanisms by which the solar-wheat soil treatment suppressed PTSL tree mortality, because this aspect was not addressed in this study. However, preplanting wheat prior to orchard establishment was as effective as preplant $\mathrm{MBr}$ fumigation in increasing tree survival from PTSL (13), even though postplant wheat intercropping in newly planted or 4-year-old, well-established peach trees did not suppress $(P \leq 0.05)$ ring nematode populations after 3 years (14).

In summary, preplant soil solarization was found to impart longlasting suppression of M. xenoplax populations and enhanced tree survival on a PTSL site. Six years after orchard establishment, tree survival was aided by the solar-wheat treatment equally as well as by $\mathrm{MBr}$ fumigation. Solarization had a more suppressive effect on M. xenoplax than did the repeated applications of a Pseudomonas spp. cocktail. Economically, soil solarization alone (approximately $\$ 500 /$ ha) appears to be cost-effective when compared with stripapplied $\mathrm{MBr}$-chloropicrin fumigation (approximately $\$ 2,500 / \mathrm{ha}$ ) and comparable with Telone II fumigation (approximately \$350/ha) (P. Fuller, TriEst Ag Group, Inc., personal communication). The results of this study support further examination of preplant soil solarization, followed by postplant peach tree intercropping with wheat, as a useful alternative for managing PTSL.

\section{Acknowledgments}

We thank R. Adams and M. A. Bacon for technical assistance.

\section{Literature Cited}

1. Brittain, J. A., and Miller, R. W. 1978. Managing peach tree short life in the Southeast. Clemson Univ. Ext. Bull. 585.

2. Byrd, D. W., Jr., Barker, K. R., Ferris, H., Nusbaum, C. J., Griffin, W. E., Small, R. H., and Stone, C. A. 1976. Two semi-automatic elutriators for extracting nematodes and certain fungi from soil. J. Nematol. 8:206-212.

3. Christie, J. R. 1959. Plant Nematodes, Their Bionomics and Control. The H. \& W. B. Drew Co., Florida.

4. Clean Air Act. 1990. Title VI. Stratospheric Ozone Protection Publication L. Pages 101-549, Section 6001. United States Congress, Washington, DC.

5. Gamliel, A., and Katan, J. 1991. Involvement of fluorescent pseudomonads and other microorganisms in increased growth response of plants in solarized soils. Phytopathology 81:494-502.
6. Horton, D., Brannen, P., Bellinger, B., Lockwood, D., and Ritchie, D. 2011. Southeastern peach, nectarine, and plum pest management and culture guide. D. Horton, P. Brannen, B. Bellinger, D. Lockwood, and D. Ritchie, eds. Univ. Ga. Coop. Ext. Serv. Bull. 1171

7. Jenkins, W. R. 1964. A rapid centrifugal-flotation technique for separating nematodes from soil. Plant Dis. Rep. 48:692.

8. Katan, J. 1981. Solar heating (solarization) of the soil for control of soilborne pests. Annu. Rev. Phytopathol. 19:211-236.

9. Kluepfel, D. A., McInnis, T. M., and Zehr, E. I. 1993. Involvement of rootcolonizing bacteria in peach orchard soils suppressive of the nematode Criconemella xenoplax. Phytopathology 83:1240-1245.

10. Kluepfel, D. A., Nyczepir, A. P., Lawrence, J. E., Wechter, P. W., and Leverentz, B. 2002. Biological control of the phytoparasitic nematode Mesocriconema xenoplax on peach trees. J. Nematol. 34:120-123.

11. Lockwood, D. W., Ferree, M. E., and Meyers, S. C. 2005. Nutrition. Pages 75-84 in: Southeastern Peach Growers' Handbook. D. Horton and D. Johnson, eds. University of Georgia College of Agriculture, Athens.

12. Miller, R. W. 1994. Estimated peach tree losses 1980 to 1992 in South Carolina: causes and economic impact. Pages 121-127 in: Proc. 6th Stone Fruit Decline Workshop.

13. Nyczepir, A. P., and Bertrand, P. F. 2000. Preplanting bahiagrass or wheat compared for controlling Mesocriconema xenoplax and short life in a young peach orchard. Plant Dis. 84:789-793.

14. Nyczepir, A. P., Bertrand, P. F., Parker, M. L., Meyer, J. R., and Zehr, E. I. 1998. Interplanting wheat is not an effective postplant management tactic for Criconemella xenoplax in peach production. Plant Dis. 82:573-577.

15. Nyczepir, A. P., Kluepfel, D. A., Lawrence, J., and Zehr, E. I. 1998. Effect of preplant solarization on ring nematode in a peach tree short life site. Pages 4/1-4/2 in: Proc. Annu. Int. Res. Conf. Methyl Bromide Alternatives Emissions Reductions, USA.

16. Nyczepir, A. P., Okie, W. R., and Beckman, T. G. 2004. Creating a short life site for Prunus rootstock evaluation on land with no innate Mesocriconema xenoplax population. HortScience 39:124-126.

17. Nyczepir, A. P., Reilly, C. C., and Okie, W. R. 1987. Effect of initial population density of Criconemella xenoplax on reducing sugars, free amino acids, and survival of peach seedlings over time. J. Nematol. 19:296-303.

18. Nyczepir, A. P., Zehr, E. I., Lewis, S. A., and Harshman, D. C. 1983. Short life of peach trees induced by Criconemella xenoplax. Plant Dis. 67:507-508.

19. Savage, E. F., and Cowart, F. F. 1942. Factors affecting peach tree longevity in Georgia. Ga. Agric. Exp. Stn. Res. Bull. 219.

20. Sharpe, R. R., Reilly, C. C., Nyczepir, A. P., and Okie, W. R. 1989. Establishment of peach in a replant site as affected by soil fumigation, rootstock, and pruning date. Plant Dis. 73:412-415.

21. Shepard, D. P., Zehr, E. I., and Bridges, W. C. 1999. Increased susceptibility to bacterial spot of peach trees growing in soil infested with Criconemella xenoplax. Plant Dis. 83:961-963.

22. Stapleton, J. J., and DeVay, J. E. 1986. Soil solarization: a non-chemical approach for management of plant pathogens and pests. Crop Prot. 5:190198.

23. USDA, NRCS. 1998. Estimating soil moisture by feel and appearance. Program Aid Number 1619. http://www.oneplan.org/Water/soilmoist.pdf

24. Weaver, D. J., Wehunt, E. J., and Dowler, W. M. 1974. Association of tree site, Pseudomonas syringae, Criconemoides xenoplax, and pruning date with short life of peach trees in Georgia. Plant Dis. Rep. 58:76-79.

25. Wechter, W. P., Glandorf, D. C. M., Derrick, W. C., Leverentz, B., and Kluepfel, D. A. 2001. Identification of genetic loci in a rhizosphere-inhabiting species of Pseudomonas involved in expression of a phytoparasitic nematode ovicidal factor. Soil Biol. Biochem. 33:1749-1758.

26. Westcott, S. W., and Kluepfel, D. A. 1993. Inhibition of Criconemella xenoplax egg hatch by Pseudomonas aureofaciens. Phytopathology 83:12451249.

27. Zehr, E. I., and Golden, J. K. 1986. Strip and broadcast treatments of dichloropropene compared for controlling Criconemella xenoplax and short life in a peach orchard. Plant Dis. 70:1064-1066. 